\title{
Assessment of rubber tree panels under crowns resistant to South American leaf blight
}

\author{
Larissa Alexandra Cardoso Moraes(1), Adônis Moreira(1), José Roberto Antoniol Fontes ${ }^{(2)}$, \\ Everton Rabelo Cordeiro(2) and Vicente Haroldo de Figueiredo Moraes ${ }^{(3)}$
}

\begin{abstract}
(1)Embrapa Soja, Rodovia Carlos João Strass, Distrito de Warta, Caixa Postal 231, CEP 86001-970 Londrina, PR, Brazil E-mail: larissa.moraes@cnpso.embrapa.br, adonis@cnpso.embrapa.br (2)Embrapa Amazônia Ocidental, Rodovia AM 010, Km 29, Zona Rural, Caixa Postal 319, CEP 69010-970 Manaus, AM, Brazil. E-mail: jose_roberto@cpa.embrapa.breverton.cordeiro@cpaa.embrapa.br (3)In memoriam
\end{abstract}

Abstract - The objective of this work was to assess the performance of panel clones under crowns resistant to South American leaf blight (Microcyclus ulei). The experiment was carried out with 18 panel clones crown-budded with Hevea pauciflora $\mathrm{x}$ H. guianensis, in a Xanthic Ferralsol (Oxisol) in Manaus, AM, Brazil. The following parameters were evaluated: dry rubber yield, plant nutritional status, and anatomical and physiological characteristics of the latex vessels. In the first three years of evaluation, the panel clones IAN 2878, IAN 2903, CNS AM 7905, CNS AM 7905 P1, and PB 28/59 showed the highest dry rubber yield potential, while the clones IAN 6158, IAN 6590, and IAN 6515 should not be recommended for crown budding. Higher potassium and copper foliar content in panel clones were associated to an increase in dry rubber yield. The simultaneous evaluation of anatomical and physiological characteristics of latex is fundamental for the selection of panel clones in the Amazon region. Crown budding is an efficient technology for South American leaf blight management in endemic regions.

Index terms: Hevea, Microcyclus ulei, Amazon, crown budding, nutritional status.

\section{Avaliação de painéis sob copas de seringueira resistentes ao mal-das-folhas}

\begin{abstract}
Resumo - O objetivo deste trabalho foi avaliar o desempenho de clones de painéis enxertados com copas resistentes ao mal-das-folhas (Microcyclus ulei). O experimento foi realizado com 18 clones de painéis enxertados com copas Hevea pauciflora x H. guianensis, em Latossolo Amarelo distrófico, em Manaus, AM. Foram avaliados os seguintes parâmetros: produtividade de borracha seca, estado nutricional das plantas e características anatômicas e fisiológicas dos vasos laticíferos. Nos três primeiros anos de avaliação, os clones de painel IAN 2878, IAN 2903, CNS AM 7905, CNS AM 7905 P1 e PB 28/59 apresentaram os maiores potenciais de produção de borracha seca, enquanto que os clones IAN 6158, IAN 6590, and IAN 6515 não devem ser recomendados para enxertia de copa. Maior conteúdo foliar de potássio e de cobre nos clones de painéis esteve associado a maiores produções de borracha seca. A avaliação simultânea de características anatômicas e fisiológicas dos vasos laticíferos é fundamental para seleção de clones de painéis na Região Amazônica. A enxertia de copa é uma tecnologia eficiente para o manejo do mal-das-folhas, em regiões endêmicas.
\end{abstract}

Termos para indexação: Hevea, Microcyclus ulei, Amazônia, enxertia de copa, estado nutricional.

\section{Introduction}

In the Amazon, South American leaf blight (SALB) caused by the fungus Microcyclus ulei P. Henn. V. Arx. has led to a decline in rubber production and to the consequent migration of Hevea plantations to other locations without the disease (Gasparotto et al., 1997). However, crossing Hevea spp. to obtain crown clones resistant to SALB has produced extremely positive results. The most promising clones achieved dry rubber yield above $1,000 \mathrm{~kg} \mathrm{ha}^{-1}$ per year in the initial two years of tapping (Moraes \& Moraes, 2008), similar to the results obtained in other rubber regions in Brazil
(Gonçalves et al., 2001a; Virgens Filho et al., 2001; Gonçalves et al., 2007; Silva et al., 2010).

The potential of Hevea brasiliensis (Willd. ex A. Juss.) Müll. Arg. to produce latex depends on genetic and environmental factors. These variables are even more complex in crown budding, since two grafts are used in the same plant, i.e., root and panel, and panel and crown - the latter being the result of an interaction between two different species of Hevea with distinct physiological and anatomical characteristics, such as diameter and number of laticiferous vessel rings, senescence, resistance to diseases, and bark thickness.

In general, regardless of the results found, studies on crown-budded clones resistant to SALB are limited 
to panel clone CNS AM $7905-H$. brasiliensis primary screening in the nursery, at Embrapa Amazônia Ocidental, Manaus, AM, Brazil (Moraes \& Moraes, 2008). This clone lacks the depressive effect of crowns from different rubber tree species on dry rubber yield, which has not been observed in experiments with other productive clones (Bahia \& Sena-Gomes, 1981; Moraes \& Moraes, 1997, 2004). However, new studies should not be limited to just one clone. It is necessary to develop other promising panel clones, in case clone CNS AM 7905 becomes susceptible to any kind of disorder, such as predisposition to tapping panel dryness.

In the crown and panel screening process, besides rubber yield, the evaluation of the anatomical, biochemical, and biophysical characteristics of latex and of the plant nutritional status are important to check the positive effect of crown clones on latex flow and regeneration (Jacob et al., 1989b; Moraes \& Moraes, 1995).

The objective of this work was to assess the performance of 18 panel clones crown-budded with $H$. pauciflora $\mathrm{x} H$. guianensis resistant to South American leaf blight (Microcyclus ulei), planted in a Xanthic Ferralsol (Oxisol) in Manaus, AM, Brazil.

\section{Materials and Methods}

The rubber tree trial was established in 2002 at the experimental area of Embrapa Amazônia Ocidental
(2053'29"S and 5958'40"W), in Manaus, AM, Brazil. The soil is a Xanthic Ferralsol (Oxisol), with high clay content ( $730 \mathrm{~g} \mathrm{~kg}^{-1}$ of clay) and the following chemical attributes: $\mathrm{pH}\left(\mathrm{H}_{2} \mathrm{O}\right), 4.3 ; 1.55 \mathrm{~g} \mathrm{~kg}^{-1}$ of total $\mathrm{N} ; 2.4 \mathrm{mg}$ $\mathrm{dm}^{-3}$ of P (Mehlich 1); $47.1 \mathrm{mg} \mathrm{dm}^{-3}$ of K; $7.2 \mathrm{mg} \mathrm{dm}^{-3}$ of Na; $0.24 \mathrm{cmol}_{\mathrm{c}} \mathrm{dm}^{-3}$ of $\mathrm{Ca} ; 0.12 \mathrm{cmol}_{\mathrm{c}} \mathrm{dm}^{-3}$ of $\mathrm{Mg} ; 1.45 \mathrm{cmol}_{\mathrm{c}} \mathrm{dm}^{-3}$ of $\mathrm{Al} ; 8.04 \mathrm{cmol}_{\mathrm{c}} \mathrm{dm}^{-3}$ of $\mathrm{H}+\mathrm{Al}$; $46.9 \mathrm{~g} \mathrm{~kg}^{-1}$ of organic matter (OM); $0.25 \mathrm{mg} \mathrm{dm}^{-3}$ of $\mathrm{Cu} ; 333.2 \mathrm{mg} \mathrm{dm}^{-3}$ of Fe; $5.15 \mathrm{mg} \mathrm{dm}^{-3}$ of $\mathrm{Mn}$; $0.68 \mathrm{mg} \mathrm{dm}^{-3}$ of $\mathrm{Zn}$ (micronutrients were extracted by Mehlich 1); 6.3 of V\% (Claessen, 1997).

The climate of the region is classified as Afi, wet tropical, according to Köppen, with abundant rainfall throughout the year (average of 2,250 mm), always higher than $60 \mathrm{~mm}$ in the month with the lowest rainfall, and average temperature of approximately $26^{\circ} \mathrm{C}$ (Vieira \& Santos, 1987).

The area was deforested in 1976 using a bulldozer, then cultivated with rubber trees until 1985 , abandoned for eleven years, and bulldozed again to remove tree trunks during soil preparation. A randomized complete block design was used with seven plants per plot and three replicates. A total of 18 panel clones were assessed (Table 1); however, clone RRIM 600 (Tjir 1 x PB 86), currently the most planted in Southeast Brazil, was not included in the present work, since it showed unsatisfactory growth in the nursery under the edaphoclimatic conditions of the region.

Table 1. Clones evaluated and their parents, Manaus, AM, Brazil ${ }^{(1)}$.

\begin{tabular}{|c|c|}
\hline Clone & Parents \\
\hline CNS AM 7905 & Hevea brasiliensis - primary nursery selection \\
\hline CNS AM 7905 P1 & Polyploid of CNS AM 7905 \\
\hline PB 28/59 & PBIG seedling \\
\hline Fx 4098 & PB $86 \times$ FB 74 \\
\hline Fx 3864 & PB 86 x FB 38 \\
\hline PB 314 & RRIM 600 (Tjir 1 x PB 86) x PB 235 [PB 5/51 (PB 56 x PB 24)] x PB S/78 \\
\hline IAN 2880 & Fx 516 (F 4542 x AVROS 363) x PB 86 \\
\hline IAN 2878 & Fx 516 (F 4542 x AVROS 363) x PB 86 \\
\hline IAN 2903 & Fx 516 (F 4542 x AVROS 363) x PB 86 \\
\hline IAN 6590 & Fx 43-651 [Fx 213 (F 4542 x AVROS 183) x AVROS 183] x PB 186 \\
\hline IAN 3156 & Fx 516 (F 4542 x AVROS 363) x PB 86 \\
\hline IAN 3044 & Fx 516 (F 4542 x AVROS 363) x PB 86 \\
\hline IAN 6158 & Fx 43-655 [Fx 213 (F 4542 x AVROS 183) x AVROS 183] x PB 186 \\
\hline IAN 6158 P4 & Polyploid of IAN 6158 \\
\hline IAN 3087 & Fx 516 (F 4542 x AVROS 363) x PB 86 \\
\hline FDR 1057 & Hevea brasiliensis \\
\hline IRCA 111 & PB 5/51 (PB 56 x PB 24) x RRIM 600 (Tjir 1 x PB 86) \\
\hline
\end{tabular}

${ }^{(1)}$ CNS, Centro Nacional de Seringueira, Amazonas; PB, Prang Besar; PBIG, Prang Besar Isolated Garden; Fx, Ford Cross; FB, Ford Belém; IAN, Instituto Agronômico do Norte; Tjir, Tjirandji; AVROS, Algemene Verening Rubber Planters Oostkust Sumatra; IRCA, Institut de Recherche sur le Coautchouc en Afrique. 
Ilegitimate seeds of $H$. brasiliensis (random crossing) were sown in sand seedbeds, and the seedlings were transplanted into the nursery at the "white point" and "spider paw" growth stages. Before seedling transplant into the final position, base grafting was done in the panel clone nursery, and bare root plants were transferred to plastic bags. The seedlings were transplanted into the final position after the second emission of mature leaves (Moraes et al., 2008). Seedling management for crown budding followed the procedures described by Zeid (1977). Crown budding was carried out using $H$. pauciflora $\mathrm{x} H$. guianensis hybrids eight months after transplanting into the final position and was concluded before the ninth month after panel clone base grafting. Plant density was 476 plants per hectare and crown budding height was $1.7 \mathrm{~m}$, according to Moraes (2002).

Before plowing, $1.0 \mathrm{Mg} \mathrm{ha}^{-1}$ of dolomitic limestone $-26.4 \%$ of $\mathrm{CaO}, 12.4 \%$ of $\mathrm{MgO}, 80.0 \%$ of effective calcium carbonate (ECC) - was applied to the soil. Two months later, a broadcast application was done using triple superphosphate $\left(686.3 \mathrm{~kg} \mathrm{ha}^{-1}\right.$ of $\left.\mathrm{P}_{2} \mathrm{O}_{5}\right)$, copper sulfate $\left(5.0 \mathrm{~kg} \mathrm{ha}^{-1}\right.$ of $\left.\mathrm{Cu}\right)$, zinc sulfate $\left(5.0 \mathrm{~kg} \mathrm{ha}^{-1}\right.$ of $\mathrm{Zn}$ ), and boric acid (1.5 kg ha-1 of B), followed by soil disaggregation using a rotary hoe. Fertilizer broadcast applications were split into six monthly doses starting in the second month, using urea (696.9 $\mathrm{kg} \mathrm{ha}^{-1}$ of $\left.\mathrm{N}\right)$, ammonium sulfate ( $464.4 \mathrm{~kg} \mathrm{ha}^{-1}$ of $\mathrm{N}$ ), and potassium chloride $\left(696.1 \mathrm{~kg} \mathrm{ha}^{-1}\right.$ of $\left.\mathrm{K}_{2} \mathrm{O}\right)$. The other cultivation treatments (hoeing, spraying, etc.) were identical to those described by Moraes et al. (2008).

In the third year after planting, leaflet samples were collected according to the method recommended by Shorrocks (1962), in order to assess the nutritional status of the plants. Total leaf contents of N, P, K, $\mathrm{Ca}, \mathrm{Mg}, \mathrm{S}, \mathrm{B}, \mathrm{Cu}, \mathrm{Fe}, \mathrm{Mn}$, and $\mathrm{Zn}$ were determined following the methodology described by Malavolta et al. (1997).

In the second year of tapping, latex samples were collected without stimulation from spiral cuts in the median part of the panel to determine contents of inorganic phosphorus ( $\mathrm{Pi}), \mathrm{Mg}$, thiols (R-SH), bursting index of lutoids (BIL), and sucrose. In test tubes containing $9.0 \mathrm{~mL}$ of $2.5 \%$ trichloroacetic acid, $1.0-\mathrm{mL}$ latex composite samples were collected from three plants per plot, from each of the three blocks, $10 \mathrm{~min}$ after tapping started. The tubes with $10 \%$ latex were shaken, placed into polystyrene boxes containing ice, and transported to the laboratory. After coagulation, the clots were pressed inside the test tubes using a glass stirring rod and removed, so that only the supernatant remained in the tubes (Moraes \& Moraes, 1995). The $\mathrm{Mg}$ content in the latex was assessed in the supernatant diluted in 2.5\% trichloroacetic acid (Moraes \& Moraes, 1997). Sucrose was determined using the anthrone method (Ashwell, 1957), while thiols (R-SH), BIL, and $\mathrm{Pi}$ were evaluated according to the methods described by Boyne \& Ellman (1972), Ribaillier (1968), and Tausski \& Shorr (1953), respectively. The circumference of the trunk was measured and virgin bark samples were collected $1.3 \mathrm{~m}$ above ground level to determine the number of latex vessel rings, density and diameter of laticiferous vessels, bark thickness, and average distance between consecutive latex vessel rings.

Tapping began in late 2007, five years after planting, when $80 \%$ of the plants had trunk circumference over $45 \mathrm{~cm}$, with two spiral-cut tappings per week, according to the following model: $1 / 2 \mathrm{~s}, \mathrm{~d} / 3,6 \mathrm{~d} / 7$, $10 \mathrm{~m} / \mathrm{y}$, et. $2.5 \%, \mathrm{~Pa}(1: 1)$ (Benesi \& Oliveira, 2000). Yield was expressed in kilograms of dry rubber per hectare per year, using the formula adapted from Melhoramento Genético da Seringueira (1987),

$$
\mathrm{DRY}=(\mathrm{ADT} / \mathrm{TF}) \mathrm{x} \text { NTT } \mathrm{x} \text { DRYTT, }
$$

in which: DRY is dry rubber productivity $\left(\mathrm{kg} \mathrm{ha}^{-1}\right.$ per year), ADT is the appropriate days for tapping, TF is the tapping frequency, NTT is the number of trees being tapped per hectare (400 plants), and DRYTT is the dry rubber yield per tree per tapping.

Dry rubber yield, plant nutritional status, and latex anatomical and physiological characteristics were analyzed using analysis of variance. Mean differences were compared using cluster analysis (Scott \& Knott, 1974 ), at $5 \%$ probability.

\section{Results and Discussion}

Over a three-year period, panel clones PB 28/59, IAN 2878, CNS AM 7905 P1, CNS AM 7905, and IAN 2903 showed statistically better performance, with average dry rubber yields over $1,800 \mathrm{~kg} \mathrm{ha}^{-1}$ per year (Table 2). These results are similar to those obtained by Gonçalves et al. (2001a), Virgens Filho et al. (2001), and Gonçalves et al. (2007) for the best clones selected for the state of São Paulo, Brazil. 
Nevertheless, the clones PB 314, IAN 6158, IAN 3087, IAN 6590, IAN 6515, IAN 6158 P4, and FDR 1057, when crown-budded, showed poor performance, with dry rubber yields below $1,000 \mathrm{~kg} \mathrm{ha}^{-1}$ per year, even though they produced good yield under other edaphoclimatic conditions (Pereira et al., 1999; Gonçalves et al., 2001b; Silva et al., 2010). The poor results found for these clones do not prevent their use in future studies carried out in other regions. Gonçalves et al. (2001b) tested nine clones from the Amazon region in a crown budding experiment, in a plateau in the state of São Paulo, and concluded that three of them had higher dry rubber yields than RRIM 600, the main clone cultivated in Brazil. Factors such as low natural soil fertility in the Amazon (Moreira \& Fageria, 2009) and crown budding with different species of rubber tree, including $H$. pauciflora $\mathrm{x} H$. guianensis (Moraes

Table 2. Dry rubber yield over a three-year period of 18 rubber tree panel clones crown-budded with Hevea pauciflora $\mathrm{x} H$. guianensis ${ }^{(1)}$.

\begin{tabular}{lrrrr}
\hline Panel & \multicolumn{4}{c}{ Dry rubber yield $\left(\mathrm{kg}^{-1} \mathrm{ha}^{-1}\right.$ per year $)$} \\
\cline { 2 - 5 } & \multicolumn{1}{c}{2008} & 2009 & \multicolumn{1}{c}{2010} & Average \\
\hline CNS AM 7905 & $1,822.8 \mathrm{~b}$ & $1,926.1 \mathrm{a}$ & $1,979.3 \mathrm{~b}$ & $1,909.4 \mathrm{a}$ \\
CNS AM 7905 P1 & $1,928.3 \mathrm{a}$ & $2,012.2 \mathrm{a}$ & $2,349.0 \mathrm{a}$ & $2,095.8 \mathrm{a}$ \\
PB 28/59 & $2,180.1 \mathrm{a}$ & $1,834.1 \mathrm{~b}$ & $1,934.8 \mathrm{~b}$ & $1,983.0 \mathrm{a}$ \\
FX 4098 & $910.3 \mathrm{~d}$ & $1,171.2 \mathrm{~b}$ & $1,539.2 \mathrm{c}$ & $1,206.9 \mathrm{c}$ \\
IAN 2880 & $1,700.0 \mathrm{c}$ & $1,383.4 \mathrm{c}$ & $1,468.8 \mathrm{c}$ & $1,517.4 \mathrm{~b}$ \\
IAN 2878 & $1,931.8 \mathrm{a}$ & $1,782.4 \mathrm{~b}$ & $1,731.7 \mathrm{~b}$ & $1,815.3 \mathrm{a}$ \\
FX 3864 & $685.7 \mathrm{e}$ & $1,617.9 \mathrm{~b}$ & $1,480.6 \mathrm{c}$ & $1,261.4 \mathrm{c}$ \\
PB 314 & $1,226.5 \mathrm{~d}$ & $1,188.6 \mathrm{c}$ & $583.4 \mathrm{e}$ & $999.5 \mathrm{~d}$ \\
IAN 2903 & $1,822.8 \mathrm{~b}$ & $2,238.8 \mathrm{a}$ & $1,431.7 \mathrm{c}$ & $1,831.1 \mathrm{a}$ \\
IAN 3156 & $1,159.0 \mathrm{~d}$ & $1,594.8 \mathrm{~b}$ & $1,069.7 \mathrm{~d}$ & $1,274.5 \mathrm{c}$ \\
IAN 3044 & $1,522.3 \mathrm{c}$ & $1,665.7 \mathrm{~b}$ & $1,463.5 \mathrm{c}$ & $1,550.5 \mathrm{~b}$ \\
IAN 6158 & $699.6 \mathrm{e}$ & $567.7 \mathrm{e}$ & $672.8 \mathrm{e}$ & $646.7 \mathrm{e}$ \\
IAN 3087 & $722.2 \mathrm{e}$ & $746.5 \mathrm{~d}$ & $972.4 \mathrm{~d}$ & $813.7 \mathrm{~d}$ \\
FDR 1057 & $1,123.6 \mathrm{~d}$ & $831.8 \mathrm{~d}$ & $700.5 \mathrm{e}$ & $885.3 \mathrm{~d}$ \\
IRCA 111 & $1,417.4 \mathrm{c}$ & $966.5 \mathrm{~d}$ & $1,175.9 \mathrm{~d}$ & $1,186.6 \mathrm{c}$ \\
IAN 6158 P4 & $460.7 \mathrm{e}$ & $796.2 \mathrm{~d}$ & $1,468.3 \mathrm{c}$ & $908.4 \mathrm{~d}$ \\
IAN 6590 & $0.0 \mathrm{f}$ & $0.0 \mathrm{f}$ & $0.0 \mathrm{~g}$ & $0.0 \mathrm{~g}$ \\
IAN 6515 & $419.7 \mathrm{e}$ & $424.3 \mathrm{e}$ & $329.6 \mathrm{f}$ & $391.2 \mathrm{f}$ \\
\hline Mean & $1,207.4$ & $1,258.1$ & $1,247.3$ & $1,237.6$ \\
Standard deviation & 624.7 & 624.5 & 609.3 & 578.0 \\
CV (\%) & 13.72 & - & - & - \\
Minimal & 0.0 & 0.0 & 0.0 & 0.0 \\
Maximum & $2,180.1$ & $2,012.2$ & $2,349.0$ & $2,096.5$ \\
\hline
\end{tabular}

${ }^{(1)}$ Means followed by equal letters in the columns do not differ by the ScottKnott test at $5 \%$ probability. In average, four trees per block were considered for the first year (2008), five trees per block for the second year (2009), and six trees per block for yield stimulation for the third year (2010).
\& Moraes, 2008), may have negatively influenced latex biosynthesis and, consequently, led to lower yields.

Except for IAN 6158, the clones evaluated had average trunk circumference above $45 \mathrm{~cm}$ (Table 3), a parameter considered ideal to start tapping (Moraes et al., 2008).

The high content of Pi found for clones PB 28/59, IAN 3044, and IAN 3156 (Table 3) may have positively influenced yield, which was not observed for clones CNS AM 7905 P1 and CNS AM 7905. According to Jacob et al. (1989a) and Moraes \& Moraes (2004), $\mathrm{Pi}$ content reflects the intensity of latex synthesis, since two molecules of isopentenyl pyrophosphate are liberated for the incorporation of isoprene into the macromolecule of latex and $\mathrm{P}$ is liberated due to the use of adenosine triphosphate (ATP). The concentration of $\mathrm{Mg}$ in the latex ranged from 4.4 to $10.3 \mathrm{mmol} \mathrm{L}^{-1}$. Only clone CNS AM 7905 had more than $10.0 \mathrm{mmol} \mathrm{L}^{-1}$ of $\mathrm{Mg}$, an amount considered non-limiting to latex biosynthesis in laticiferous vessels (Moraes \& Moraes, 1997, 2008).

Similarly to the results obtained by Jacob et al. (1989b) and Moraes \& Moraes (1997), the clones that had higher dry rubber yields (CNS AM 7905 P1, CNS AM 7905, and PB 28/59) showed the lowest sucrose contents in the latex, possibly due to a more intensive use of this compound during latex biosynthesis and to the dilution effect caused by higher latex export.

R-SH content ranged from 0.05 to $0.58 \mathrm{mmol} \mathrm{L}^{-1}$ (IAN 2880 and IAN 6515, respectively), with a mean value of $0.20 \mathrm{mmol} \mathrm{L}^{-1}$, considered low by Moraes \& Moraes (2004). It was expected that the clones with higher dry rubber yields show the highest R-SH contents and the lowest BIL values, since thiols play a vital role in maintaining membrane integrity, leading to low BIL values and preventing premature coagulation of the latex (D’Auzac \& Jacob, 1989); however, this was not observed in the present study. These results could be explained by the higher number of latex vessel rings found for clone PB 28/59 and by the higher diameter and density of laticiferous vessels for clones IAN 2880, CNS AM 7905, and CNS AM 7905 P1, which caused higher latex flow before coagulation.

The number and diameter of latex vessel rings are important characteristics of the laticiferous system that are directly correlated to latex yield (Hénon \& Nicolas, 1989; Webster \& Paardekooper, 1989; Mesquita et al., 
2006). However, this is not a general rule, as observed by Tixier (1953) for clone AVROS 256, in Indochina, Southeast Asia. In the present study, clones FDR 1057, PB 314, and IAN 3087 showed a large number of latex vessel rings, above 29, which was the number reported by Gonçalves et al. (2001b) for clone RRIM 600, but had low average dry rubber yields. Therefore, using these variables as the only criteria to select crown budding clones may cause loss of promising materials, such as clones Fx 4098 and Fx 3864, which showed average dry rubber yields above $1,200 \mathrm{~kg} \mathrm{ha}^{-1}$ per year. Factors including $\mathrm{Mg}, \mathrm{Pi}$, and sucrose contents in the latex, among others, may also interfere positively or negatively with yield.

The results observed for bark thickness were higher than those obtained by Gonçalves et al. (2001b) for Amazonian clones and for RRIM $600(5.6 \pm 0.7 \mathrm{~mm})$, cultivated in the state of São Paulo. Average distance between consecutive latex vessel rings (ADBCLVR) ranged from 125.9 to $511.0 \mathrm{~mm}$ (IAN 2878 and IAN 6158, respectively), and the three clones with the highest dry rubber yields were within the group with the lowest ADBCLVR values. As expected, an inverse relationship between the diameter of laticiferous vessels and ADBCLVR was observed.

Due to the lack of standard concentrations of foliar nutrients for the crown under study, data obtained for crown hybrids $H$. pauciflora $\mathrm{x} H$. rigidifolia and H. pauciflora $\times$ H. guianensis by Pereira \& Pereira (1986) and Moraes \& Moraes (2008), respectively, were used as reference. The mean foliar contents of $\mathrm{N}$ $\left(24.1 \pm 3.7 \mathrm{~g} \mathrm{~kg}^{-1}\right), \mathrm{P}\left(1.3 \pm 0.2 \mathrm{~g} \mathrm{~kg}^{-1}\right), \mathrm{K}\left(6.8 \pm 1.9 \mathrm{~g} \mathrm{~kg}^{-1}\right)$, $\mathrm{Ca}\left(5.5 \pm 1.1 \mathrm{~g} \mathrm{~kg}^{-1}\right), \quad \mathrm{S}\left(1.6 \pm 0.2 \mathrm{~g} \mathrm{~kg}^{-1}\right), \quad \mathrm{Cu}$ $\left(6.1 \pm 0.8 \mathrm{mg} \mathrm{kg}^{-1}\right)$, and $\mathrm{Mn}\left(163.3 \pm 40.5 \mathrm{mg} \mathrm{kg}^{-1}\right)$ found in the present study were close to the range observed by these authors. However, the mean foliar contents of B $\left(49.1 \pm 5.0 \mathrm{mg} \mathrm{kg}^{-1}\right), \mathrm{Fe}\left(93.8 \pm 5.2 \mathrm{mg} \mathrm{kg}^{-1}\right)$, and $\mathrm{Zn}$ $\left(27.5 \pm 4.9 \mathrm{mg} \mathrm{kg}^{-1}\right)$ were lower than those reported by Moraes \& Moraes (2008).

The clones with mean dry rubber yields above $1,900 \mathrm{~kg} \mathrm{ha}^{-1}$ (CSN AM 7905 P1, PB 28/59, and CSN AM 7905) showed the highest foliar contents of $\mathrm{Cu}$ and $\mathrm{K}$, but intermediary foliar content of $\mathrm{Mg}$

Table 3. Anatomical and physiological characteristics of latex produced by 18 rubber tree panel clones crown-budded with Hevea pauciflora $\mathrm{x} H$. guianensis in the second year of tapping ${ }^{(1)}$.

\begin{tabular}{|c|c|c|c|c|c|c|c|c|c|c|c|}
\hline Clone & $\begin{array}{c}\mathrm{Pi} \\
\left(\mathrm{mg} \mathrm{L}^{-1}\right) \\
\end{array}$ & $\begin{array}{c}\mathrm{Mg} \\
\text { (molar) }\end{array}$ & $\begin{array}{l}\text { Sucrose } \\
---(\text { mmol L }\end{array}$ & $\begin{array}{l}\text { R-SH } \\
\left.\mathrm{L}^{-1}\right)---\end{array}$ & $\begin{array}{l}\text { BIL } \\
(\%) \\
\end{array}$ & $\mathrm{d}(5 \mathrm{~mm})$ & Number of rings & LVD & $\begin{array}{c}\text { BT } \\
-(\mathrm{mm}) \\
\end{array}$ & ADBCLVR & $\begin{array}{c}\text { Circumference } \\
(\mathrm{cm})\end{array}$ \\
\hline CNS AM 7905 & $11.3 \mathrm{~d}$ & $7.0 \mathrm{~b}$ & $4.4 \mathrm{e}$ & $0.09 \mathrm{e}$ & $42.0 \mathrm{a}$ & $66.1 \mathrm{a}$ & $27 d$ & $13.6 \mathrm{a}$ & $8.0 \mathrm{~b}$ & $208.0 \mathrm{c}$ & $54.0 \mathrm{~b}$ \\
\hline CNS AM 7905 P1 & $7.1 \mathrm{~d}$ & $6.6 b$ & $2.5 \mathrm{f}$ & $0.11 \mathrm{e}$ & $40.0 \mathrm{a}$ & $66.1 \mathrm{a}$ & $39 \mathrm{c}$ & $13.9 \mathrm{a}$ & $11.6 \mathrm{a}$ & $206.9 \mathrm{c}$ & $50.6 \mathrm{~b}$ \\
\hline PB 28/59 & $29.3 b$ & $10.3 \mathrm{a}$ & $4.8 \mathrm{e}$ & $0.06 \mathrm{e}$ & $29.3 b$ & $62.1 \mathrm{~b}$ & $55 \mathrm{a}$ & $10.6 \mathrm{~b}$ & $10.4 \mathrm{a}$ & $189.1 \mathrm{c}$ & $58.0 \mathrm{a}$ \\
\hline Fx 4098 & $9.3 \mathrm{~d}$ & $9.1 \mathrm{a}$ & $11.1 \mathrm{a}$ & $0.09 \mathrm{e}$ & $41.1 \mathrm{a}$ & $60.8 b$ & $13 \mathrm{e}$ & $10.9 b$ & $7.8 \mathrm{~b}$ & $404.7 b$ & $57.8 \mathrm{a}$ \\
\hline IAN 2880 & $10.3 \mathrm{~d}$ & $6.2 b$ & $7.4 \mathrm{c}$ & $0.05 \mathrm{e}$ & $30.6 b$ & $68.8 \mathrm{a}$ & $43 b$ & $13.6 \mathrm{a}$ & $9.1 \mathrm{a}$ & $177.1 \mathrm{c}$ & $53.4 \mathrm{~b}$ \\
\hline IAN 2878 & $8.0 \mathrm{~d}$ & $4.9 \mathrm{c}$ & $6.6 \mathrm{c}$ & $0.11 \mathrm{e}$ & $34.5 b$ & $65.7 \mathrm{a}$ & $39 \mathrm{c}$ & $12.0 \mathrm{~b}$ & $7.2 \mathrm{~b}$ & $125.9 \mathrm{c}$ & $52.6 \mathrm{~b}$ \\
\hline Fx 3864 & $10.8 \mathrm{~d}$ & $8.3 \mathrm{a}$ & $10.7 \mathrm{a}$ & $0.29 \mathrm{c}$ & $32.4 \mathrm{~b}$ & $60.3 b$ & $15 \mathrm{e}$ & $10.4 b$ & $8.6 \mathrm{a}$ & $368.9 b$ & $53.6 \mathrm{~b}$ \\
\hline PB 314 & $13.2 \mathrm{c}$ & $9.9 \mathrm{a}$ & $6.5 \mathrm{c}$ & $0.10 \mathrm{e}$ & $34.3 b$ & $65.1 \mathrm{a}$ & $39 \mathrm{c}$ & $13.7 \mathrm{a}$ & $8.8 \mathrm{a}$ & $197.7 \mathrm{c}$ & $46.1 \mathrm{~b}$ \\
\hline IAN 2903 & $7.1 \mathrm{~d}$ & $4.4 \mathrm{c}$ & $5.6 \mathrm{~d}$ & $0.17 \mathrm{~d}$ & $36.3 \mathrm{a}$ & $56.9 \mathrm{~b}$ & $33 \mathrm{c}$ & $10.1 \mathrm{~b}$ & $7.6 \mathrm{~b}$ & $184.8 \mathrm{c}$ & $48.6 b$ \\
\hline IAN 3156 & $16.0 \mathrm{c}$ & $6.9 \mathrm{~b}$ & $5.8 \mathrm{~d}$ & $0.29 \mathrm{c}$ & $33.3 b$ & $63.4 \mathrm{a}$ & $35 c$ & $11.0 \mathrm{~b}$ & $9.9 \mathrm{a}$ & $235.2 \mathrm{c}$ & $50.6 b$ \\
\hline IAN 3044 & $17.6 \mathrm{c}$ & $7.6 \mathrm{a}$ & $7.4 \mathrm{c}$ & $0.22 \mathrm{~d}$ & $20.4 \mathrm{c}$ & $59.3 b$ & $44 b$ & $11.0 \mathrm{~b}$ & $9.0 \mathrm{a}$ & $225.7 \mathrm{c}$ & $49.6 b$ \\
\hline IAN 6158 & $8.2 \mathrm{~d}$ & $5.0 \mathrm{c}$ & $8.0 \mathrm{~b}$ & $0.29 \mathrm{c}$ & $29.2 b$ & $65.1 \mathrm{a}$ & $25 d$ & $10.8 b$ & $6.4 \mathrm{~b}$ & $511.0 \mathrm{a}$ & $42.2 b$ \\
\hline IAN 3087 & $8.4 d$ & $9.1 \mathrm{a}$ & $10.0 \mathrm{a}$ & $0.24 \mathrm{~d}$ & $30.1 b$ & $55.6 \mathrm{~b}$ & $47 b$ & $10.2 b$ & $9.8 \mathrm{a}$ & $370.3 b$ & $62.6 \mathrm{a}$ \\
\hline FDR 1057 & $8.2 \mathrm{~d}$ & $8.8 \mathrm{a}$ & $9.1 \mathrm{~b}$ & $0.19 \mathrm{~d}$ & $31.4 \mathrm{~b}$ & $58.7 \mathrm{~b}$ & $39 \mathrm{c}$ & $13.2 \mathrm{a}$ & $8.8 \mathrm{~b}$ & $248.9 \mathrm{c}$ & $64.4 \mathrm{a}$ \\
\hline IRCA 111 & $10.2 d$ & $6.7 b$ & $7.4 \mathrm{c}$ & $0.09 \mathrm{e}$ & $30.9 b$ & $65.6 \mathrm{a}$ & $31 d$ & $11.3 \mathrm{~b}$ & $10.3 \mathrm{a}$ & $254.3 \mathrm{c}$ & $54.9 \mathrm{~b}$ \\
\hline IAN 6158 P4 & $9.4 \mathrm{~d}$ & $4.7 \mathrm{c}$ & $5.6 \mathrm{~d}$ & $0.33 \mathrm{c}$ & $30.4 b$ & $61.8 \mathrm{~b}$ & $22 d$ & $11.6 \mathrm{~b}$ & $6.8 \mathrm{~b}$ & $265.1 \mathrm{c}$ & $47.9 \mathrm{~b}$ \\
\hline IAN 6590 & $11.8 \mathrm{~d}$ & $5.8 \mathrm{~b}$ & $5.6 \mathrm{~d}$ & $0.45 b$ & $42.5 \mathrm{a}$ & $65.4 \mathrm{a}$ & $21 d$ & $10.6 \mathrm{~b}$ & $7.1 \mathrm{~b}$ & $189.6 \mathrm{c}$ & $56.1 \mathrm{a}$ \\
\hline IAN 6515 & $65.5 \mathrm{a}$ & $8.3 \mathrm{a}$ & $10.4 \mathrm{a}$ & $0.58 \mathrm{a}$ & $36.0 \mathrm{a}$ & $58.9 \mathrm{~b}$ & $23 \mathrm{~d}$ & $9.8 \mathrm{~b}$ & $5.5 \mathrm{~b}$ & $136.5 \mathrm{c}$ & $52.3 \mathrm{~b}$ \\
\hline Mean & 14.5 & 7.2 & 7.1 & 0.20 & 35.0 & 62.5 & 33 & 11.6 & 8.5 & 250.0 & 53.1 \\
\hline Standard deviation & 13.8 & 1.8 & 2.4 & 0.14 & 5.5 & 3.7 & 11.5 & 1.4 & 1.6 & 101.0 & 5.5 \\
\hline CV $(\%)$ & 18.31 & 17.19 & 13.81 & 24.07 & 12.96 & 7.33 & 13.70 & 10.36 & 12.82 & 24.31 & 10.88 \\
\hline Minimal & 7.1 & 4.4 & 2.5 & 0.05 & 20.4 & 55.6 & 13.0 & 9.8 & 5.5 & 129.9 & 42.2 \\
\hline Maximum & 65.9 & 10.3 & 11.1 & 0.58 & 42.5 & 68.8 & 55.0 & 13.9 & 11.6 & 511.0 & 64.4 \\
\hline
\end{tabular}

${ }^{(1)}$ Means followed by equal letters, in the columns, do not differ by the Scott-Knott test at 5\% probability. Pi, inorganic phosphorus in the latex; Mg, magnesium in the latex; R-SH, thiols; BIL, bursting index of lutoids; d (5 mm), density of laticiferous vessels in $5 \mathrm{~mm}$ per ring; LVD, laticiferous vessel diameter; BT, bark thickness; ADBCLVR, average distance between consecutive latex vessel rings. 
Table 4. Foliar nutrient content in 18 rubber tree panel clones crown-budded with Hevea pauciflora x H. guianensis ${ }^{(1)}$.

\begin{tabular}{|c|c|c|c|c|c|c|c|c|c|c|c|}
\hline \multirow[t]{2}{*}{ Clone } & $\mathrm{N}$ & $\mathrm{P}$ & $\mathrm{K}$ & $\mathrm{Ca}$ & $\mathrm{Mg}$ & $\mathrm{S}$ & B & $\mathrm{Cu}$ & $\mathrm{Fe}$ & $\mathrm{Mn}$ & $\mathrm{Zn}$ \\
\hline & \multicolumn{7}{|c|}{ - } & \multicolumn{4}{|c|}{ - $\left(\mathrm{mg} \mathrm{kg}^{-1}\right)$ - - } \\
\hline CNS AM 7905 & $25.9 \mathrm{a}$ & $1.7 \mathrm{a}$ & $12.3 \mathrm{a}$ & $3.8 \mathrm{~b}$ & $2.2 \mathrm{c}$ & $1.7 \mathrm{a}$ & $46.4 \mathrm{a}$ & $8.1 \mathrm{a}$ & $87.3 \mathrm{a}$ & $119.1 \mathrm{~b}$ & $28.3 b$ \\
\hline CNS AM 7905 P1 & $26.0 \mathrm{a}$ & $1.5 \mathrm{a}$ & $8.9 b$ & $3.9 b$ & $2.3 \mathrm{c}$ & $1.7 \mathrm{a}$ & $54.5 \mathrm{a}$ & $7.1 \mathrm{a}$ & $91.5 \mathrm{a}$ & $139.8 b$ & $32.9 b$ \\
\hline PB 28/59 & $26.2 \mathrm{a}$ & $1.4 \mathrm{a}$ & $8.4 \mathrm{~b}$ & $5.5 \mathrm{a}$ & $2.4 \mathrm{c}$ & $1.6 \mathrm{a}$ & $51.6 \mathrm{a}$ & $7.3 \mathrm{a}$ & $91.4 \mathrm{a}$ & $170.0 \mathrm{~b}$ & $27.8 \mathrm{~b}$ \\
\hline FX 4098 & $25.8 \mathrm{a}$ & $1.5 \mathrm{a}$ & $7.1 \mathrm{c}$ & $4.4 b$ & $1.8 \mathrm{c}$ & $1.8 \mathrm{a}$ & $47.7 \mathrm{a}$ & $6.8 \mathrm{a}$ & $94.1 \mathrm{a}$ & $128.9 b$ & $28.8 \mathrm{~b}$ \\
\hline IAN 2880 & $24.5 \mathrm{a}$ & $1.2 \mathrm{~b}$ & $6.0 \mathrm{c}$ & $6.5 \mathrm{a}$ & $1.7 \mathrm{c}$ & $1.4 \mathrm{a}$ & $46.8 \mathrm{a}$ & $5.9 \mathrm{a}$ & $89.8 \mathrm{a}$ & $81.6 \mathrm{~b}$ & $17.6 \mathrm{c}$ \\
\hline IAN 2878 & $25.3 \mathrm{a}$ & $1.2 \mathrm{~b}$ & $5.2 \mathrm{c}$ & $5.8 \mathrm{a}$ & $3.1 \mathrm{c}$ & $1.6 \mathrm{a}$ & $46.0 \mathrm{a}$ & $6.4 \mathrm{a}$ & $87.5 \mathrm{a}$ & $170.3 b$ & $22.5 \mathrm{c}$ \\
\hline FX 3864 & $24.1 \mathrm{a}$ & $1.1 \mathrm{~b}$ & $6.8 \mathrm{c}$ & $6.2 \mathrm{a}$ & $2.5 \mathrm{c}$ & $1.5 \mathrm{a}$ & $36.4 \mathrm{~b}$ & $5.4 \mathrm{a}$ & $103.3 \mathrm{a}$ & $189.5 \mathrm{a}$ & $26.8 \mathrm{~b}$ \\
\hline PB 314 & $21.1 \mathrm{a}$ & $1.1 \mathrm{~b}$ & $6.6 \mathrm{c}$ & $6.2 \mathrm{a}$ & $2.2 \mathrm{c}$ & $1.4 \mathrm{a}$ & $56.3 \mathrm{a}$ & $4.8 \mathrm{a}$ & $89.9 \mathrm{a}$ & $169.5 b$ & $35.9 \mathrm{a}$ \\
\hline IAN 2903 & $24.8 \mathrm{a}$ & $1.3 b$ & $5.9 \mathrm{c}$ & $6.0 \mathrm{a}$ & $2.0 \mathrm{c}$ & $1.4 \mathrm{a}$ & $53.6 \mathrm{a}$ & $6.5 \mathrm{a}$ & $84.9 \mathrm{a}$ & $169.6 \mathrm{~b}$ & $26.8 \mathrm{~b}$ \\
\hline IAN 3156 & $23.1 \mathrm{a}$ & $1.4 \mathrm{a}$ & $7.0 \mathrm{c}$ & $4.3 b$ & $1.9 \mathrm{c}$ & $1.6 \mathrm{a}$ & $44.1 \mathrm{a}$ & $6.4 \mathrm{a}$ & $96.3 \mathrm{a}$ & $205.6 \mathrm{a}$ & $27.7 \mathrm{~b}$ \\
\hline IAN 3044 & $22.3 \mathrm{a}$ & $1.1 \mathrm{~b}$ & $5.8 \mathrm{c}$ & $6.8 \mathrm{a}$ & $2.7 \mathrm{c}$ & $1.7 \mathrm{a}$ & $45.9 \mathrm{a}$ & $5.4 \mathrm{a}$ & $97.1 \mathrm{a}$ & $228.9 a$ & $36.6 \mathrm{a}$ \\
\hline IAN 6158 & $22.9 \mathrm{a}$ & $1.3 \mathrm{~b}$ & $7.0 \mathrm{c}$ & $4.5 \mathrm{a}$ & $1.9 \mathrm{c}$ & $1.4 \mathrm{a}$ & $50.2 \mathrm{a}$ & $5.4 \mathrm{a}$ & $90.1 \mathrm{a}$ & $191.5 \mathrm{a}$ & $29.1 \mathrm{c}$ \\
\hline IAN 3087 & $24.0 \mathrm{a}$ & $1.3 b$ & $6.7 \mathrm{c}$ & $3.9 \mathrm{~b}$ & $2.1 \mathrm{c}$ & $1.8 \mathrm{a}$ & $51.6 \mathrm{a}$ & $6.0 \mathrm{a}$ & $93.7 \mathrm{a}$ & $156.3 b$ & $30.1 b$ \\
\hline FDR 1057 & $26.3 \mathrm{a}$ & $1.5 \mathrm{a}$ & $7.6 \mathrm{c}$ & $6.2 \mathrm{a}$ & $3.5 b$ & $1.9 \mathrm{a}$ & $47.0 \mathrm{a}$ & $6.4 \mathrm{a}$ & $99.8 \mathrm{a}$ & $150.1 \mathrm{~b}$ & $26.5 b$ \\
\hline IRCA 111 & $21.9 \mathrm{a}$ & $1.4 \mathrm{a}$ & $6.9 \mathrm{c}$ & $5.3 \mathrm{a}$ & $1.8 \mathrm{c}$ & $1.7 \mathrm{a}$ & $51.5 \mathrm{a}$ & $5.6 \mathrm{a}$ & $99.5 \mathrm{a}$ & $151.8 \mathrm{~b}$ & $22.8 b$ \\
\hline IAN 6158 P4 & $21.7 \mathrm{a}$ & $1.2 \mathrm{~b}$ & $2.3 \mathrm{~d}$ & $5.2 \mathrm{a}$ & $4.9 \mathrm{a}$ & $1.8 \mathrm{a}$ & $57.9 \mathrm{a}$ & $5.9 \mathrm{a}$ & $100.9 \mathrm{a}$ & $132.0 \mathrm{~b}$ & $19.4 \mathrm{c}$ \\
\hline IAN 6590 & $25.2 \mathrm{a}$ & $1.2 \mathrm{~b}$ & $6.4 \mathrm{c}$ & $7.4 \mathrm{a}$ & $2.9 \mathrm{c}$ & $1.8 \mathrm{a}$ & $47.1 \mathrm{a}$ & $5.3 \mathrm{a}$ & $92.5 \mathrm{a}$ & $250.3 a$ & $26.6 \mathrm{~b}$ \\
\hline IAN 6515 & $22.7 \mathrm{a}$ & $1.2 \mathrm{~b}$ & $5.9 \mathrm{c}$ & $6.2 \mathrm{a}$ & $2.8 \mathrm{c}$ & $1.6 \mathrm{a}$ & $49.0 \mathrm{a}$ & $5.9 \mathrm{a}$ & $98.1 \mathrm{a}$ & $134.3 \mathrm{~b}$ & $28.2 \mathrm{~b}$ \\
\hline Mean & 24.1 & 1.3 & 6.8 & 5.5 & 2.5 & 1.6 & 49.1 & 6.1 & 93.8 & 163.3 & 27.5 \\
\hline Standard deviation & 3.7 & 0.2 & 1.9 & 1.1 & 0.8 & 0.2 & 5.0 & 0.8 & 5.2 & 40.5 & 4.9 \\
\hline CV (\%) & 13.6 & 14.86 & 20.93 & 14.70 & 23.02 & 11.68 & 10.21 & 15.76 & 9.31 & 20.34 & 16.22 \\
\hline Minimal & 21.1 & 1.1 & 2.3 & 3.8 & 1.7 & 1.4 & 36.4 & 4.8 & 84.9 & 81.6 & 17.6 \\
\hline Maximum & 26.3 & 1.7 & 12.3 & 7.4 & 4.9 & 1.9 & 57.9 & 7.3 & 100.9 & 250.3 & 36.6 \\
\hline
\end{tabular}

${ }^{(1)}$ Means followed by equal letters, in the columns, do not differ by the Scott-Knott test, at $5 \%$ probability

(Table 4), considered an important criterion for crown selection (Moraes \& Moraes, 2004). According to Jacob et al. (1989b) and Tungngoen et al. (2009), higher foliar content of $\mathrm{Cu}$ is an important feature, since this nutrient inhibits the activity of sucrose synthase, the enzyme responsible for sucrose neosynthesis in the latex, and maintains the substrate for latex synthesis available. The foliar content of $\mathrm{K}$ is equally important - this nutrient participates in glycolysis, respiration, laticiferous vessel formation, and osmotic rebalancing after tapping (Jacob et al., 1989b). These results show that dry rubber yield can be improved by using the correct fertilizer management indicated by the assessment of soil fertility and the nutritional status of rubber trees.

\section{Conclusions}

1. Crown budding is an efficient technology for South American leaf blight management in endemic regions.

2. Panel clones IAN 2878, IAN 2903, CNS AM 7905, CNS AM 7905 P1, and PB 28/59 have the highest average dry rubber yield potential, while clones IAN 6158, IAN 6590, and IAN 6515 are not recommended for the management system used in this study.

3. The simultaneous evaluation of anatomical and physiological characteristics of latex is fundamental for the selection of panel clones, under the edaphoclimatic conditions of the Amazon region.

4. Higher foliar content of $\mathrm{Cu}$ and $\mathrm{K}$ is associated to higher dry rubber yields of panel clones crown-budded with Hevea pauciflora x H. guianensis.

\section{Acknowledgements}

To Maria da Conceição Loureiro Campelo, Renaldo Silva de Araújo, Francisco Exgidras Leite Magalhães, and Sérgio de Araújo Silva, from Embrapa Amazônia Ocidental, for data collection and support in laboratory analyses.

\section{References}

ASHWELL, G. Colorimetric analysis of sugar. In: COLOWICK, S.P.; KAPLAN, N.O. (Ed.). Methods in enzymology. New York: Academic Press, 1957. p.73-75. 
BAHIA, D.B.; SENA-GOMES, A.R. Panel versus crown in some clones of rubber tree (Hevea sp.). Revista Theobroma, v.11, p.203-208, 1981.

BENESI, J.F.C.; OLIVEIRA, M.A. de. Sangrador de seringueira: sangria de seringueira. São Paulo: Senar, 2000. 57p.

BOYNE, A.F.; ELLMAN, G.L. A methodology for analysis of tissue sulfhydryl components. Analytical Biochemistry, v.46, p.639-653, 1972.

CLAESSEN, M.E.C. (Org.). Manual de métodos de análises de solo. Rio de Janeiro: Embrapa-CNPS, 1997. 212p.

D'AUZAC, J.; JACOB, J.J. The composition of latex from Hevea brasiliensis as a laticiferous cytoplasm. In: D'AUZAC, J.; JACOB, J.L.; CHRESTIN, H. (Ed.). Physiology of rubber tree latex. Boca Raton: CRC, 1989. p.59-96.

GASPAROTTO, L.; SANTOS, A.F. dos; PEREIRA, J.C.R.; FERREIRA, F.A. Doenças da seringueira no Brasil. Brasília: Embrapa-SPI; Manaus: Embrapa-CPAA, 1997. 168p.

GONÇALVES, P. de S.; BORTOLETTO, N.; FURTADO, E.L.; SAMBUGARO, R.; BATAGLIA, O.C. Desempenho de clones de seringueira da série IAC 300 selecionados para a região noroeste do Estado de São Paulo. Pesquisa Agropecuária Brasileira, v.36, p.589-599, 2001a.

GONÇALVES, P. de S.; BORTOLETTO, N.; SAMBUGARO, R.; FURTADO, E.L.; BATAGLIA, O.C.; ORTOLANI, A.A; GODOY JÚNIOR, G. Desempenho de clones de seringueira de origem amazônica no planalto do Estado de São Paulo. Pesquisa Agropecuária Brasileira, v.36, p.1469-1477, 2001 b.

GONÇALVES, P. de S.; SILVA, M. de A.; AGUIAR, A.T. da E.; MARTINS, M.A.; SCALOPPI JUNIOR, E.J.; GOUVÊA, L.R.L. Performance of new Hevea clones from IAC 400 series. Scientia Agricola, v.64, p.241-248, 2007.

HÉNON, J.M.; NICOLAS, D. Relation between anatomical characteristics of the laticiferous system and latex yield: search for early selection criteria. In: D'AUZAC, J.; JACOB, J.L.; CHRESTIN, H. (Ed.). Physiology of rubber tree latex. Boca Raton: CRC, 1989. p.31-55.

JACOB, J.L.; PREVÓT, J.C.; KEKWICK, G.O. General metabolism of Hevea brasiliensis latex (with the exception of isoprenic anabolism). In: D'AUZAC, J.; JACOB, J.L.; CHRESTIN, H. (Ed.). Physiology of rubber tree latex. Boca Raton: CRC, 1989a. p.101-144.

JACOB, J.L.; PREVÓT, J.C.; ROUSSEL, D.; LACROTTE, R.; SERRES, E.; D'AUZAC, J.; ESCHBACH, J.M.; OMONT, H. Yield limiting factors, latex physiological parameter, latex diagnosis, and clonal typology. In: D'AUZAC, J.; JACOB, J.L.; CHRESTIN, H. (Ed.). Physiology of rubber tree latex. Boca Raton: CRC, 1989b. p.348-382.

MALAVOLTA, E.; VITTI, G.C.; OLIVEIRA, S.A. de. Avaliação do estado nutricional das plantas: princípios e aplicações. 2.ed. Piracicaba: Associação Brasileira para Pesquisa do Potássio e do Fosfato, 1997. 319p.

MESQUITA, A.C.; OLIVEIRA, L.E.M.; MAZZAFERA, P.; DELÚ-FILHO, N. Anatomical characteristics and enzymes of the sucrose metabolism and their relationship with latex yield in the rubber tree (Hevea brasiliensis Muell. Arg.). Brazilian Journal of Plant Physiology, v.18, p.263-268, 2006.

MELHORAMENTO genético da seringueira. Manaus: Embrapa-CNPSD, 1989. 23p. (Embrapa-CNPSD. Documentos, 10).

MORAES, V.H. de F. Altura da enxertia de copa em seringueira. Agrotrópica, v.14, p.55-60, 2002.

MORAES, V.H. de F.; MORAES, L.A.C. Características fisiológicas do látex do clone de Hevea brasiliensis Fx 4098, sob diferentes copas enxertadas de H. pauciflora. Revista de Ciências Agrárias, n.42, p.97-107, 2004.

MORAES, V.H. de F.; MORAES, L.A.C. Desempenho de clones de copa de seringueira resistentes ao mal-das-folhas. Pesquisa Agropecuária Brasileira, v.43, p.1495-1500, 2008.

MORAES, V.H. de F.; MORAES, L.A.C. Diagnóstico do látex em sangria precoce de seringueira com copas enxertadas: possibilidade do emprego na seleção precoce de clones de copa e painel. Agrotrópica, v.7, p.49-62, 1995.

MORAES, V.H. de F.; MORAES, L.A.C. Efeito de copas enxertadas de seringueira (Hevea spp.) sobre o teor de magnésio e a regeneração do látex no painel do clone Fx 3899. Agrotrópica, v.9, p.59-66, 1997.

MORAES, V.H. de F.; MORAES, L.A.C.; MOREIRA, A. Cultivo da seringueira com copas enxertadas resistentes ao mal-das-folhas. Manaus: Embrapa Amazônia Ocidental, 2008. 44p. (Embrapa Amazônia Ocidental. Documentos, 63).

MOREIRA, A.; FAGERIA, N.K. Soil chemical attributes of Amazonas State, Brazil. Communications in Soil Science and Plant Analysis, v.40, p.2912-2925, 2009.

PEREIRA, A.V.; PEREIRA, E.B.C. Adubação de seringais de cultivo na Amazônia (primeira aproximação). Manaus: Embrapa-CNPSD, 1986. 32p. (Embrapa-CNPSD. Circular técnica, 8).

PEREIRA, A.V.; VENTURIN, N.; PEREIRA, E.B.C.; FIALHO, J. de F.; JUNQUEIRA, N.T.V.; GONÇALVES, P. de S. Avaliação preliminar do desempenho de clones de seringueira (Hevea spp.) na região de Goiânia. Cerne, v.5, p.24-35, 1999.

RIBAILLIER, D. Action in vitro de certain íon minéraux et composés organiques sur la stabilité des lutoïds du latex d'Hevea. Révue Générale des Caoutchoucs et Plastiques, v.45, p.1395-1398, 1968.

SCOTT, A.J.; KNOTT, M.A. A cluster analysis method for grouping means in the analysis of variance. Biometrics, v.30, p.507-512, 1974.

SHORROCKS, V.M. Leaf analysis as a guide to nutrition of Hevea brasiliensis. V. Leaf sampling technique for mature trees. Journal of the Rubber Research Institute of Malaysia, v.17, p.167-190, 1962.

SILVA, J.Q.; GONÇALVES, P. de S.; SCARPARE FILHO, J.A.; COSTA, R.B. da. Agronomical performance and profitability of exploitation systems in four rubber tree clones in São Paulo State. Bragantia, v.69, p.843-854, 2010. 
TAUSSKY, H.H.; SHORR, E.A. A microcolorimetric method for the determination of inorganic phosphorus. Journal of Biological Chemistry, v.202, p.675-685, 1953.

TIXIER, P. Examen anatomique des écorces d'Hevea. Paris: Institut de Recherches sur le Caoutchouc en Indochine, 1953. 112p. (Annual report).

TUNGNGOEN, K.; KONGSAWADWORAKUL, P.; VIBOONJUN, V.; KATSUHARA, M.; BRUNEL, N.; SAKR, S.; NARANGAJAVANA, J.; CHRESTIN, H. Involvement of HbPIPe; 1 and HbTIP 1;1 aquaporins in ethylene stimulation of latex yield through regulation of water exchanges between inner liber and latex cells in Hevea brasiliensis. Plant Physiology, v.151, p.843-856, 2009.
VIEIRA, L.S.; SANTOS, P.C.T.C. dos. Amazônia: seus solos e outros recursos naturais. São Paulo: Agronômica Ceres, 1987. 416p.

VIRGENS FILHO, A. de C.; MOREIRA, A.; CASTRO, P.R. de C.E. Efeito da calagem e adubação da seringueira no estado nutricional e produção de borracha seca. Pesquisa Agropecuária Brasileira, v.36, p.1019-1026, 2001.

WEBSTER, C.C.; PAARDEKOOPER, E.C. The botany of the rubber tree. In: WEBSTER, C.C.; BAULKWILL, W.J. (Ed.). Rubber. New York: Longman, 1989. p.57-84.

ZEID, P. Interim report on the development of advanced planting material. In: RUBBER RESEARCH INSTITUTE OF MALAYSIA PLANTER'S CONFERENCE, 1., 1977, Kuala Lumpur Proceedings. Kuala Lumpur: RRIM, 1977. p.21-46.

Received on March 22, 2010 and accepted on April 8, 2011 